\title{
広島県三原鉱山産デーナ石およびフェナス石*
}

\section{Danalite and Phenacite from the Mihara Mine, Hiroshima Prefecture, Japan}

\author{
青 木 義 和 (Yoshikazu Aoki)** \\ 肥田昇 (Noboru Hida) \\ 前田憲二郎 (Kenjiro Maeda) $)^{* * * *}$
}

\section{1. は し がき}

本邦に産するべリリウム鉱物としては, リョクチュウ石, キンリョク石, ガドリン石，へルビンなどがあげられるが，広島県三原鉱山には，我国にお いては珍しいデーナ石およびフェナス石を産するので，これらの鉱物の記載 を行ないたい。

$$
\text { デーナ石は, ヘルビン } \mathrm{Mn}_{4}\left(\mathrm{BeSiO}_{4}\right)_{3} \mathrm{~S} \text {, ゲントヘルバイト } \mathrm{Zn}_{4}\left(\mathrm{BeSiO}_{4}\right)_{3} \mathrm{~S}
$$
とともにヘルビン族鉱物の一員であり，理想端成分が $\mathrm{Fe}_{4}\left(\mathrm{BeSiO}_{4}\right)_{3} \mathrm{~S}$ で, ホウソーダ石と同構造のテクト珪酸塩鉱物である。今回ここに記載する三原 鉱山産のものが，我国における初めての産出である。フェナス石は, $\mathrm{Be}_{2} \mathrm{SiO}_{4}$ とカンラン石組成をもつが，ケイアェン鈗と同構造の三方晶系に属する鉱物 で，柴田（1939）および長島・桜井（1969）により，長野県山口村および岐 阜県苗木地方のペグマタイト産のものにつき，それぞれ報告されている。

これらの鉱物は，地質調査所におけるべリリウム鉱床探査計画の一部とし て，三原鉱山を調査した際に見出されたもので，その調査にあたっては，当 時の地質調査所中国出張所 青柳信義所長 (現資料室長)，同所鉱床部坂巻幸

* 1968 年 2 月鉱山地質学会および岩鉱学会連合学術大会（仙台）および 1968 年 10 月 3 鉱学会共催学術講演会 (岡山) にて一部講演。

** 九州大学理学部地質学教室

*** 工業技術院東北工業技術試験所

**** 工業技術院地質調査所技術部 なお,この研究は, 青木および肥田が地質調查所在職中に行われた。 
雄技官, および三原鉱業株式会社番匠嘉久蔵氏はじめ現地の方々に多大の援 助を賜った。また, 国立科学博物館加藤昭博士には, 原稿を読んで批判して いただき，さらに貴重な文献を御教示いただいた。以上の方々に心から感謝 の意を表する。

\section{2. 産地および地質概略}

三原鉱山は，広岛県三原市宗郷町部落の南々西約 $500 \mathrm{~m}$ に位置するホタ ル石の鉱山（古くは銅鈗を稼行）であるが，現在は稼行していない。

鉱山附近の地質は, 広島型花崗岩類とその上にルーフ状に分布する古生層 から成る。古生層は, 主に粘板岩・チャート・変輝緑岩・石灰岩から成り, 広島型のクロウンモ花崗岩の貫入により，ホルンフェルス化およびスカルン 化をうけている（添田，1963）。

スカルンは鉱物組成により，カイジュウ石一チョウ石一ホタル石一クロウ ンモスカルン, 縞状スカルン*, チョウ石一ホタル石一テッアクチノセン石 スカルン，およびベスブ石一ホタル石一サーラキ石一ザクロ石スカルンなど に分けられる。な拉，スカルン中にジリュウテッ鉱，オウドウ鉱，センアェ ン鉱などを seam 状，鉱染状に含さ場合がある。

広島型花崗岩は，主にセキエイ，アルカリチョウ石，クロウンモ，および 少量のシャチョウ石から成るが，スカルンの近くでは，径 $0.4 \mathrm{~mm}$ 以下のホ タル石を含むことがある。スカルンとの接触部の一部 又は，その近くで含 ホタル石閃長岩扎よび含ホタル石モンゾ二岩化して拈り，ホタル石のほかに， テッアクチノセン石，サーラキ石，クロウンモ，などのスカルン構成鉱物を とり込んでいる場合がある。

\section{3. デーナ 石}

デーナ石は，含ホタル石モンゾニ岩中に，径約 $0.2 \sim 1.5 \mathrm{~mm}$ の黄褐色な いし赤褐色粒状をなして点在し，肉眼的には径約 $1 〜 4 \mathrm{~mm}$ の紫色ないし深 紫色粒状のホタル石と共存するのが特徵である。

* 緑色部，白色部および黒色部が，1〜 $5 \mathrm{~mm}$ の巾で彎曲した縞状を呈するもので，主 として緑色部はテッアクチノセン石, ホタル石, 白色部はホタル石, チョウ石, ザ クロ石, ベスブ石, 黒色部はジテッ鉱, テッアクチノセン石などから構成される。 
- 36 - 広島県三原鉱山産デーナ石およびフェナス石

第 1 表 デーナ石, ヘルビンおよびゲントヘルバイトのX線粉末データ

\begin{tabular}{|c|c|c|c|c|c|c|c|c|}
\hline \multirow[b]{3}{*}{ h k 1} & \multicolumn{4}{|c|}{ Danalite } & \multirow{2}{*}{\multicolumn{2}{|c|}{$\begin{array}{c}\text { Helvine } \\
(3)\end{array}$}} & \multirow{2}{*}{\multicolumn{2}{|c|}{$\begin{array}{c}\text { Genthelvite } \\
(4)\end{array}$}} \\
\hline & \multicolumn{2}{|c|}{ (1) } & \multicolumn{2}{|c|}{ (2) } & & & & \\
\hline & $\mathrm{d}(\AA)$ & I & $\mathrm{d}(\AA)$ & I & $\mathrm{d}(\AA)$ & I & $\mathrm{d}(\AA)$ & I \\
\hline 002 & & & 4.087 & 1 & & & 4.07 & $\mathrm{~m}$ \\
\hline 012 & 3. 68 & 25 & 3. 678 & 4 & 3.71 & 2 & 3. 65 & $\mathrm{~m}$ \\
\hline 112 & 3. 36 & 100 & 3. 347 & 10 & 3. 38 & 10 & 3. 33 & vs \\
\hline 022 & 2.904 & 10 & 2.897 & 1 & 2.93 & $1 / 2$ & 2.875 & $\mathrm{~m}$ \\
\hline 013 & 2.599 & 30 & 2.591 & 3 & 2.62 & 3 & 2.577 & s \\
\hline 222 & 2. 376 & 12 & 2. 368 & 2 & 2. 386 & 2 & 2. 351 & $\mathrm{~m}$ \\
\hline 023 & 2. 282 & 8 & 2.274 & 1 & 2.287 & 1 & 2.258 & $\mathrm{w}$ \\
\hline \multirow[t]{2}{*}{123} & 2.195 & 35 & 2.193 & 5 & 2.213 & 5 & 2.174 & vs \\
\hline & & & 2. 129 & 1 & 2. 152 & $1 / 2$ & & \\
\hline 004 & 2.056 & 8 & 2. 052 & 1 & 2.066 & $1 / 2$ & 2.036 & $\mathrm{~m}$ \\
\hline 033,114 & 1.936 & 65 & 1.932 & 7 & 1.949 & 7 & 1.918 & vs \\
\hline 024 & 1.837 & 13 & 1.833 & 2 & 1.849 & 2 & 1.822 & $\mathrm{~s}$ \\
\hline 124 & 1.791 & 8 & 1.790 & 1 & 1.803 & 1 & 1.778 & $\mathrm{w}$ \\
\hline 224 & 1.678 & 13 & 1.678 & 3 & 1.689 & 3 & 1.663 & $\mathrm{~s}$ \\
\hline 015,134 & 1.610 & 11 & 1.607 & 2 & 1.621 & 2 & 1.596 & $\mathrm{~m}$ \\
\hline 025,234 & 1.526 & 7 & 1.524 & 1 & 1.536 & 1 & 1.513 & $\mathrm{w}$ \\
\hline 125 & 1. 499 & 10 & 1. 498 & 2 & 1.513 & 2 & 1. 489 & $\mathrm{~s}$ \\
\hline 044 & 1.453 & 13 & 1.451 & 4 & 1.462 & 4 & 1. 441 & s \\
\hline 035,334 & 1.410 & 10 & 1. 410 & 3 & 1.418 & 3 & 1.399 & $\mathrm{~s}$ \\
\hline 006,244 & 1.369 & 12 & 1.368 & 3 & 1.380 & 4 & 1. 359 & $\mathrm{~s}$ \\
\hline 116,235 & 1.333 & 14 & 1.333 & 3 & 1. 342 & 4 & 1.322 & $\mathbf{s}$ \\
\hline 026 & & & 1. 297 & $1 / 2$ & & & 1.288 & $\mathrm{w}$ \\
\hline 145 & 1.267 & 10 & 1. 268 & 4 & 1.277 & 4 & 1.258 & $\mathrm{~s}$ \\
\hline$a(\AA)$ & \multicolumn{2}{|c|}{8.216} & \multicolumn{2}{|c|}{ 8. 196} & \multicolumn{2}{|c|}{ 8. 272} & \multicolumn{2}{|c|}{$8.12 \pm 0.01$} \\
\hline $\mathrm{mol} \%$ & \multicolumn{2}{|c|}{$\mathrm{Da}_{57} \mathrm{He}_{28} \mathrm{Ge}_{15}$} & \multicolumn{2}{|c|}{$\mathrm{Da}_{65} \mathrm{He}_{28} \mathrm{Ge}_{7}$} & \multicolumn{2}{|c|}{$\mathrm{Da}_{8} \mathrm{He}_{92} \mathrm{Ge}_{0}$} & \multicolumn{2}{|c|}{$\mathrm{Da}_{22} \mathrm{He}_{3} \mathrm{Ge}_{75}$} \\
\hline
\end{tabular}

1) Mihara mine, Hiroshima pref., present work.

2) Needle-point Mountain, British Columbia, Thompson (1957).

3) Yagisawa mine, Nagano pref., 吉村・吉永 (1959).

4) Jos, Northern Nigeria, Knorring and Dyson (1959). 
顕微鏡下では，わずかに黄褐色味を帯びた自形ないし半自形で，不規則な 割れ目が多数存在する。光学的には等方性で異常消光は認められない。アル カリチョウ石およびホタル石と密接するが，時には，クロウンモ，テッアク チノセン石およびフェナス石を交代したような組織を呈する場合が観察され る。

第 2 表 デーナ石, ヘルビンおよびゲントヘルバイトの化学分析值, 屈折率 および比重

\begin{tabular}{|c|c|c|c|c|}
\hline & \multicolumn{2}{|c|}{ Danalite } & \multirow{2}{*}{$\frac{\text { Helvine }}{(3)}$} & \multirow{2}{*}{$\frac{\text { Genthelvite }}{(4)}$} \\
\hline & (1) & (2) & & \\
\hline $\mathrm{SiO}_{2}$ & 32.09 & 34.08 & 33.62 & 30.70 \\
\hline $\mathrm{BeO}$ & 11.47 & 16.32 & 12.88 & 12.39 \\
\hline $\mathrm{Al}_{2} \mathrm{O}_{3}$ & 2.53 & - & 1.21 & 0.18 \\
\hline $\mathrm{TiO}_{2}$ & 0.37 & - & - & - \\
\hline $\mathrm{FeO}$ & 25.79 & 30.66 & 2.24 & 11.73 \\
\hline $\mathrm{MnO}$ & 12.78 & 13. 28 & 45.46 & 1.72 \\
\hline $\mathrm{ZnO}$ & 7.66 & 2.97 & 1.20 & 40.56 \\
\hline $\mathrm{CaO}$ & 3. 16 & - & 0.30 & $\operatorname{tr}$ \\
\hline $\mathrm{MgO}$ & 0.53 & - & $\operatorname{tr}$ & $\operatorname{tr}$ \\
\hline $\mathrm{CO}_{2}$ & 0.45 & - & - & - \\
\hline $\mathrm{H}_{2} \mathrm{O}^{+}$ & 0.45 & - & 0.02 & - \\
\hline $\mathrm{H}_{2} \mathrm{O}^{-}$ & 0.29 & - & & - \\
\hline $\mathrm{S}$ & 4. 36 & 5.61 & 5.64 & 5.50 \\
\hline & 101.93 & 102.92 & 102.57 & 102.78 \\
\hline $\mathrm{S}=\mathrm{O}$ & 2.18 & 2.80 & 2.81 & 2.74 \\
\hline Total & 99.75 & 100.12 & 99.76 & 100.04 \\
\hline Mol\% & $\mathrm{Da}_{57} \mathrm{He}_{28} \mathrm{Ge}_{15}$ & $\mathrm{Da}_{66} \mathrm{He}_{29} \mathrm{Ge}_{5}$ & $\mathrm{Da}_{5} \mathrm{He}_{93} \mathrm{Ge}_{2}$ & $\mathrm{Da}_{22} \mathrm{He}_{3} \mathrm{Ge}_{75}$ \\
\hline $\mathrm{n}(\mathrm{NaD})$ & $1.754 \pm 0.002$ & 1. 752 & 1.732 & 1.745 \\
\hline S. G. & $3.28 \pm 0.01$ & 3. 32 & 3.22 & 3. 62 \\
\hline
\end{tabular}

1) Mihara mine, Hiroshima pref., present work. Analyst: K. Maeda.

2) Imalka, Siberia, Grigoriev (1944).

3) Casa Ventura, Southern Rhodesia, Knorring (1959).

4) Jos, Northern Nigeria, Knorring and Dyson (1959). 
$\mathrm{X}$ 線回折の結果は第 1 表に示す通りであるが，比較のために端成分に近い 八木沢鉱山産へルビン(吉村・吉永, 1959; 第 1 図の 18), Jos 産ゲントヘル バイト (Knorring and Dyson, 1959; 同図 16), および三原鉱山産デーナ 石に近い成分をもつ Needle-point Mountain 産デーナ石 (Thompson, 1957 ; 同図 14）のデータも合せて表示した。シリコンを内部標準試料として, 013, 123, 044, 145 の各ピークの位置を精密測定した結果, 格子定数は,

$$
\mathrm{a}=8.216 \AA
$$

であった。X 線回折パターンおよび格子定数ともに Needle-point Mountain 産デーナ石のデータとかなりよく一致する。

デーナ石を含を岩石を 150 200 メッシュに粉砕し, 磁選および重液分離 した試料の化学分析結果を第 2 表に示す。X 線回折結果を表示した場合と同 様に, 端成分に近いCasa Ventura 産へルビン (Knorring, 1959; 第 1 図 17), Jos 産ゲントヘルバイト，および三原鉱山産のものと成分が似ている Imalka 産デーナ石 (Grigoriev, 1944; 同図 11) のデータを比較のために呈 示した。鉱物分離に際し, 微量のクロウンモその他の不純物を完全に取り除 くことが出来ず, $\mathrm{Ca}, \mathrm{Mg}, \mathrm{CO}_{2}, \mathrm{H}_{2} \mathrm{O}^{+}, \mathrm{H}_{2} \mathrm{O}^{-}$などが結果として出ているの で，化学式を揭げていないが，成分的には $\mathrm{Da}_{57} \mathrm{He}_{28} \mathrm{Ge}_{15}$ あるいはこれに非 常に近いデーナ石である(第 1 図参照)。

なお，浸液法（NaD 線使用）による屈折率とバーマン比重計で測定した 比重を，第 2 表の分析値の下欄に掲げておいた。

\section{4.フェナス 石}

フェナス石は, 三原鉱山第 3 号坑内に 小規模に露出するカイジュウ石一 チョウ石一ホタル石一クロウンモスカルン，およびこれと接する含ホタル石 モンゾニ岩中に産する。

第 3 号坑は, 坑口崩落のために現在は観察不可能であるが, カイジュり石 一チョウ石一ホタル石一クロウンモスカルンは, 巾約 $20 \sim 50 \mathrm{~cm}$, 最大巾約 $3 \mathrm{~m}$ の帯状をなして, 含ホタル石モンゾ二岩と接する。その境界はかなり明 瞭である。このスカルンは緑黒色で, 肉眼では緑黒色のクロウンモおよび淡 紫色のホタル石は認められるが，フェナス石その他の構成鉣物は認め難い。

顕微鏡下では無色で, 丸味のある六角形, 長方形, あるいは柳葉状の形を 
し, 一方向に䢃開が認められ, 双晶を形成している場合もある。大きさは一 般に小さく, 一辺が $0.08 \sim 0.3 \mathrm{~mm}$ 程度である。鮮緑色のクロウンモ, 少量 のアルカリ長石, シャチョウ石とともに, 径 $1 \mathrm{~mm}$ 前後のホタル石の粒間 に少量存在する。クロウンモは, 大きさが $0.08 \times 0.25 \mathrm{~mm}$ 程度のものが多 数集まって集合体を形成し, 微粒のジテッ鈗を伴なう。所により, カイジュ ウ石およびンーダフッ石によって虫喰い状に交代され，黄緑色に変じてい る。

含ホタル石モンゾニ岩中のフェナス石は, 粒状で径が $0.15 \mathrm{~mm}$ に達する ものもあるが， ほとんどのものは数 10 ミクロン以下と小さく，その量も非 常に少ない。クロウンモ, テッアクチノセン石などと共に変じてデーナ石お よびカリチョウ石を生成している。

Minas Geraes 産のフェナス石 (ASTM，9-431) とともに，カイジュウ 石一チョウ石一クロウンモスカルン中のフェナス石の比重值と光学性とを第 3 表に示したが, 比重が少し大きいほかは非常によく一致している。

第 3 表 フェナス石の光学性と比重

\begin{tabular}{c|c|c}
\hline & $\begin{array}{c}\text { Mihara mine, } \\
\text { Hiroshima Pref. } \\
\text { (present work) }\end{array}$ & $\begin{array}{c}\text { Minas Geraes, } \\
\text { Brazil } \\
\text { (ASTM 9-431) }\end{array}$ \\
\hline S. G. & $2.968 \pm 0.002$ & $2.964 \pm 0.007$ \\
\hline$\varepsilon$ & 1.670 & $1.670 \pm 0.002$ \\
$\omega$ & 1.653 & $1.654 \pm 0.002$ \\
$\varepsilon-\omega$ & 0.017 & 0.016 \\
Optic Sign & uniaxial(t) & uniaxial(t) \\
\hline
\end{tabular}

同じスカルン中のフェナスの石の試料粉末を，スライドガラス上に塗布し てX 線回折データを得た。第 4 表にみられる通り, Minas Geraes 産フェ ナス石のデータと極めてよい一致を示す。

なお，再三の磁選および重液分離にも拘らず，含ホタル石モンゾ二岩中の フェナス石の純粋試料が得られなかったので，その比重測定やX 線回折実験 などは行なっていない。また，上記 2 種の産状を示すフェナス石は, 双方と も量的に化学分析できるだけの純粋試料が得られず, 従って化学分析は行な っていない。 
- 40 - 広島県三原鉱山産デーナ石およびフェナス石

第 4 表 フェナス石の $\mathrm{X}$ 線粉末データ

\begin{tabular}{|c|c|c|c|c|}
\hline \multirow[b]{2}{*}{ h k 1} & \multicolumn{2}{|c|}{ (1) } & \multicolumn{2}{|c|}{ (2) } \\
\hline & $\mathrm{d}(\AA)$ & I & $\mathrm{d}(\AA)$ & I \\
\hline 110 & 6.26 & 22 & 6.25 & 40 \\
\hline 021 & & & 4. 52 & 3 \\
\hline 012 & 3. 854 & 18 & 3.86 & 25 \\
\hline 211 & 3. 660 & 62 & 3. 66 & 80 \\
\hline 300 & 3. 604 & 25 & 3. 601 & 30 \\
\hline 202 & 3. 279 & 6 & 3. 279 & 3 \\
\hline 220 & 3. 118 & 100 & 3. 119 & 100 \\
\hline 122 & 2.901 & 10 & 2.903 & 17 \\
\hline 131 & 2.815 & 10 & 2.817 & 13 \\
\hline 113 & 2.516 & 60 & 2.518 & 75 \\
\hline 410 & 2.358 & 28 & 2.358 & 70 \\
\hline 042 & 2. 260 & 4 & 2.262 & 5 \\
\hline 303 & 2.185 & 60 & 2. 187 & 60 \\
\hline 330 & 2.079 & 23 & 2. 079 & 50 \\
\hline 104 & 2.025 & 3 & 2.026 & 3 \\
\hline 241 & 1.981 & 7 & 1.982 & 9 \\
\hline 502 & 1.915 & 8 & 1.914 & 9 \\
\hline 214 & 1.843 & 3 & 1.842 & 3 \\
\hline 422 & 1.826 & 4 & 1.829 & 3 \\
\hline 600 & 1.796 & 6 & 1.798 & 5 \\
\hline 413 & 1.789 & 10 & 1.790 & 15 \\
\hline 152 & 1.755 & 3 & 1.755 & 3 \\
\hline 431 & 1.735 & 6 & 1.735 & 7 \\
\hline 520 & 1.730 & 10 & 1.730 & 11 \\
\hline 333 & 1.658 & 16 & 1.6581 & 17 \\
\hline 404 & 1.639 & 5 & 1. 6392 & 3 \\
\hline 161 & 1.615 & 2 & 1. 6154 & 3 \\
\hline
\end{tabular}

1) Mihara mine, Hiroshima pref., present work.

2) Minas Geraes, Brazil, ASTM 9-431. 


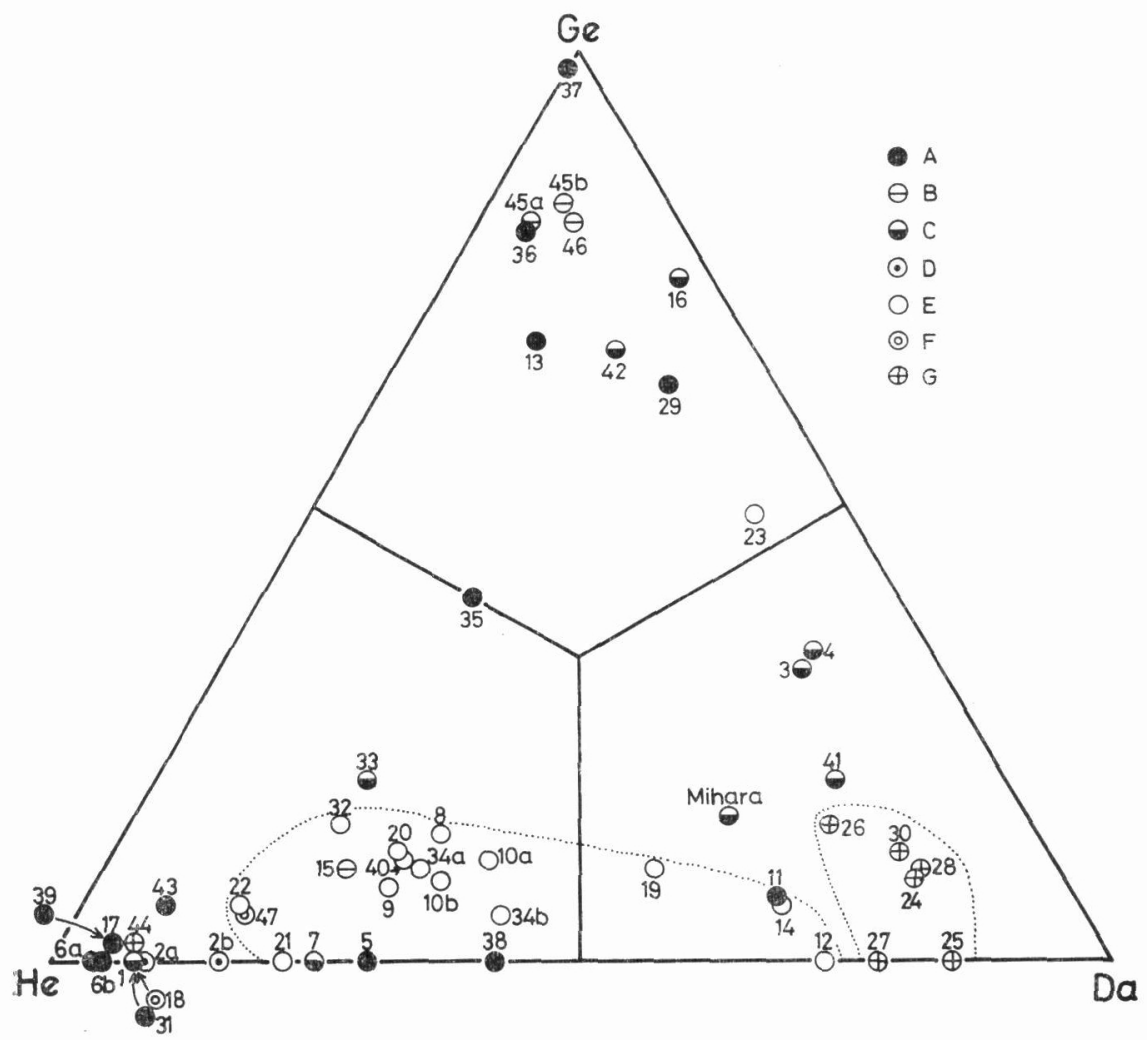

第1図 ヘルビン族鉱物の組成と産状 $\mathrm{A}$ ：ペグマタイトから産するもの， B：グラ イゼンから産するもの，C：花崗岩質岩中に産するもの， D：片麻岩中に産 するもの, E：スカルン中に産するもの, F：マンガン鉱床から産するもの, $\mathrm{G}$ : 熱水脈（抢よび熱水鉱床）中に産するもの。

1 10a. Glass et al. (1944), 10b. Gruner (1944), 11. Grigoriev (1944), 12. Ramdohr et al. (1954), 13. Eskova (1957), 14. Thompson (1957), 15. Kalenov (1959), 16. Knorring et al. (1959), 17. Knorring (1959), 18. Yoshinaga (1959), 19. Litsenmaier (1960), 20 28. Kingsburg (1961), 29. Vasil'ev (1961), 30. Dolomanova et al. (1963), 31 37. Oftedal et al. (1963), 38. Strunz et al. (1964), 39. Chistyakova et al. (1966), 40. Gordillo (1966), 41. Marmo et al. (1966), 42. Morgan (1967), 43. Ivanov (1969), 44. Čech et al. (1969), 45〜46. Haapala et al. (1972)，47. 松原ら (1973)。なお a, b 等は同一産地の子のにつき, データが 2 種以上あることを示す。 


\section{5. 考察}

第 1 図は，へルビンーデーナ石一ゲントヘルバイト三角図に，既に報告さ れているデータと三原鉱山産のものを図示したものである。ここで, 化学分 析值が与えられていても, 産地・産状の不明なものは除外した。

三角図の中央部，デーナ石端成分近傍，およびヘルビンーゲントヘルバイ 卜系のほડ゙中央部附近の組成のものの産出がまだ報告されていないが，組成 と産状との関係をみると,

（1）スカルン中に産するものは， 1 例を除き， $\mathrm{Da}_{15} \sim \mathrm{Da}_{75}, \mathrm{He}_{25} \sim \mathrm{He}_{80}$, $\mathrm{Ge}_{20}$ 以下,

（2）熱水脈中のものは, 1 例を除き, $\mathrm{Da}_{65} \sim \mathrm{Da}_{85}, \mathrm{He}_{10} \sim \mathrm{He}_{25}, \mathrm{Ge}_{15}$ 以下,

（3）ペグマタイト産のものは, ヘルビンーデーナ石系のヘルビン領域, お よびゲントヘルバイト領域内,

の組成領域内にそれぞれ分布していることがわかる。但し，（2）の熱水脈中 に産するもののらち，30 以外のもの (24 28) は全て同一地方 (Cornwall の 3 鉱山， 2 地方）の産なので，值がまとまるのはある 程度当然のことかも しれない。他の産状のものは，データが少ないので一概に論じられないが， 花崗岩質岩中に産するものは, さらに，花崗岩中に産するもの $(3,4,16,41$, 42) と閃長岩中に産するもの $(1,7,33)$ とに小分けされ，前者は $\mathrm{Da}_{20} \sim \mathrm{Da}_{65}$, $\mathrm{Ge}_{20} \sim \mathrm{Ge}_{75}, \mathrm{He}_{16}$ 以下の領域, 後者はへルビン領域内に限られる。三原鉱山 産のものについて云えば，デーナ石領域に点示されるのはもちろんであるが， (1)，(2) の領城の近くにありながら，それらのいずれにも属さず，上に述べ た花諵岩中に産するものの領域にも入らないといら興味ある部分に点示され る。

広島型のクロウンモ花崗岩は，スカルンの近く，またはスカルンとの接触 部の一部で, 含ホタル石モンゾニ岩と化しており，その中にデーナ石を含む 場合は，フェナス石を産するカイジュウ石一チョウ石一ホタル石一クロウン モスカルンの接触部かその近くに限られていることは, 既に述べた。

一般に，花崗岩質岩の貫入に伴なって，既存岩のスカルン化が行われた場 合, 花崗岩質岩体内での物質の移動が充分でなければ，スカルンとの接触部 からは花崗岩質岩体内の珪酸分が除去され，相対的にアルカリ，アルミナな どに富む岩石の生成を見ることは，野外でも（Tilley，1951)，実験室でも 
(Winkler and Johannes, 1963) よく知られた事或である。

従って，当鉱山においても，スカルンと接する花崗岩は珪酸分を除去され， セキエイが非常に少なく，相対的にカリチョウ石やシャチョウ石に富むモン ゾ二岩と化したものと思われる。その際, ベリリウムの大部分は, モンゾニ 岩体内でデーナ石を形成するために用いられたものであろう（青木・肥田, 1974)。

また，局部的にモンゾニ岩中に捕獲されたフェナス石，クロウンモなどか ら，デーナ石やカリチョウ石が生成されている場合が認められるが，これは 次のような反応によるものと思われる。即ち, 各鉱物を理想組成で表わせば,

$$
\begin{aligned}
& 3 \mathrm{Be}_{2} \mathrm{SiO}_{4}+\mathrm{K}_{2} \mathrm{Fe}_{6}\left[\mathrm{Si}_{6} \mathrm{Al}_{2} \mathrm{O}_{20}\right](\mathrm{OH})_{4}+2 \mathrm{FeS}+3 \mathrm{SiO}_{2} \\
& \text { フェナン石 テックロウ・モ(アナイト) シリニウテッ鉱 セキエ1 } \\
& \rightarrow 2 \mathrm{Fe}_{4}\left[\mathrm{Be}_{3} \mathrm{Si}_{3} \mathrm{O}_{12}\right] \mathrm{S}+2 \mathrm{KAISi}_{3} \mathrm{O}_{8}+2 \mathrm{H}_{2} \mathrm{O} \text {. }
\end{aligned}
$$

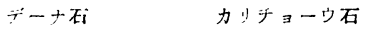

実際には，クロウンモ，デーナ石およびカリチョウ石はそれぞれ固溶体を 形成しているであろらし，センアェン鉱や他のスカルン鉱物も反応に関与し たかもしれないから，もっと複雑な反応を考えなければならないであろら。 ただしこのような現象は，スカルンと接する極く一部のモンゾニ岩中にし か観察されないので，局部的なものと見た方が妥当であろら（青木・肥田， 1974)。

\section{文献}

1）青木義和・肥田 昇：航山地質, 24, 201 (1974).

2) Čech, F. and Povondra, P.: Acta Univ. Carolinae, Geol., 1, 1 (1969).

3) Chistyakova, M.B. and Moleva, V.A.: Tr. Min. Muz., Akad. Nauk SSSR, No. 17, 240 (1966).

4) Dolomanova, E.I. and Moleva, V.A.: Tr. Min. Muz., Akad. Nauk SSSR, No. 14, 215 (1963).

5) Eskova, E.M.: Dokl. Akad. Nauk SSSR, 116, 481 (1957).

6) Glass, J.J., Jahns, R.H. and Stevens, R.E.: Amer. Mineral., 29, 163 (1944).

7) Gordillo, C.E.: Actas Jornadas Geol. Argent., 1966(3), 209 (1966).

8) Grigoriev, I.F.: Dokl. Akad. Nauk SSSR, 44, 114 (1944).

9) Gruner, J.W.: Econ. Geol., 39, 444 (1944). 
10) Haapala, I. and Ojanperä P.: Geol. Surv. Finland, Bull., 259, 1 (1972).

11) Ivanov, I.M.: Spis. Bulg. Geol. Druzh., 30, 67 (1969).

12) Kalenov, A.D. : Zap. Vses. Min. Obshch., 88, 481 (1959).

13) Kingsbury, A.W.G.: Min. Mag., 32, 921 (1961).

14) Knorring, O. von: Min. Mag., 32, 87 (1959).

15) - and Dyson, P.: Amer. Mineral., 44, 1294 (1959).

16) Litsenmaǐer, N.V.: Zap. Vses. Min. Obshch., 89, 466 (1960)

17) Marmo, V., Hoffren, V., Hytönen, K., Kallio, P., Lindholm, O. and Siivola, J.: Bull. Comm. géol. Finlande, 221, 1 (1966).

18）松原 聡・加藤 昭·桜井欽一・坂田嘉雄 - 長島弘三：国立科博研報, 16, 149 (1973).

19) Morgan, W.C.: Min. Mag., 36, 60 (1967).

20) 長島弘三·桜井欽一：鉱物雑, 9, 258 (1969).

21) Oftedal, I. and Saeb $\varnothing$, P. Chr.: Norsk Geol. Tidssk., 43, 405 (1963).

22) Pavlova, I.G., Beknazarov, K.B. and Sal'dau, É.P.: Zap. Vses. Min. Obshch., 95, 674 (1966).

23) Ramdohr, P. and Ramdohr, H.: Geol, För. Förh., Stockholm, 76, 381 (1954).

24）柴田秀賢：地質雑，46，465 (1939).

25）添田 晶： 国内鉄鋼原料調査，第 2 報，通産省， 465 (1963).

26) Strunz, H. and Tennyson, Ch.: Aufschluss, 15, 119 (1964).

27) Thompson, R.M.: Can. Mineral., 6, 68 (1957).

28) Tilley, C.E. : Min. Mag., 29, 621 (1951).

29) Vasil'ev, V.A.: Zap. Vses. Min. Obshch., 90, 571 (1961).

30) Winkler, H.G.F. and Johannes, W.: Naturwiss., 50, 730 (1963).

31) 吉村豊文·吉永真弓： 鉱物雑, 4, 34 (1959).

32) Yoshinaga, M.: Mem. Fac. Sci. Kyushu Univ., Ser. D., 9, 47 (1959). 